\title{
Evaluation of minimal erythema dose in patients who use dihydropyridinic calcium channel blockers
}

\section{Dihidropiridin Türevi Kalsiyum Kanal Blokeri Kullananlarda Minimal Eritem Dozunun Değerlendirilmesi}

\author{
Serkan DEMIRKAN*, Ekin SAVK, Neslihan SENDUR, Goksun KARAMAN, Meltem USLU \\ Kirikkale University, Department of Dermatology, Kirikkale / TURKEY
}

\begin{abstract}
Aim: One of the most frequent and reliable methods for determining phototoxicity is to monitor the minimal erythema dose(MED) related to UVA after using the drug.

In our study, it was aimed to determine whether dihydropyridine-derived calcium channel blockers cause phototoxicity.

Material and Methods: Eight open areas of $1 \mathrm{~cm} 2$ were left on the backs of the patients. Eight different doses of UVA were applied to these 8 areas starting at $2 \mathrm{j} / \mathrm{cm} 2$ and increasing to $16 \mathrm{j} / \mathrm{cm} 2$; After 24 hours, the first area which had significant erythema was checked. This value is defined as minimal erythematous dose (MED). MED values of patients were measured before treatment and on the 7th day of treatment.
\end{abstract}

Results: Thirty-nine hypertensive patients, 20 female and 19 male, were included in the study.

Conclusion: Dihydropyridine-derived calcium channel blockers did not cause a change in MED for UVA and therefore did not cause phototoxicity.

Keywords: minimal erythema dose; phototoxicity; calcium channel blocker; nifedipine; amlodipine

\section{Öz}

Amaç: Bir ilaca bağlı fototoksisitenin belirlenmesinde en sık ve güvenilir yöntem ilacı kullanmaya başladıktan sonra özellikle UVA'ya ait minimal eritem dozu (MED) değişimini gözlemektir. Çalışmamızda fotosensitiviteye yol açabileceği belirtilen hipertansiyon ilaçlarından dihidropiridin türevi kalsiyum kanal blokerlerinin fotosensitiviteye sebep olup olmadıklarının saptanması amaçlanmıştır.

Gereç ve Yöntemler: Hastaların sırtlarında $1 \mathrm{~cm} 2$ lik 8 adet açık alan bırakılmıştır. Bu 8 alana $2 \mathrm{j} / \mathrm{cm} 2$ dozundan başlanarak $16 \mathrm{j} / \mathrm{cm} 2$ 'ye kadar artan 8 farklı dozda UVA uygulanmış; 24 saat sonra ilk hangi alanda sınırları belirgin eritem oluştuğuna bakılmıştır. Bu değer minimal eritem dozu(MED) olarak belirlenmiştir. Hastaların tedavi öncesi ve tedavinin 7. gününde MED değerleri ölçülmüştür.

Bulgular: Çalışmaya 20'si kadın, 19'u erkek olmak üzere 39 hipertansiyon hastası dahil edilmiştir.

Tartışma: Dihidropiridin türevi kalsiyum kanal blokerilerinin UVA için MED değerinde değişiklikliğe neden olmadığı dolayısıyle fototoksisiteye sebep olmadığı görülmüştür.

Anahtar kelimeler: minimal eritem dozu; fototoksisite; kalsiyum kanal blokeri; nifedipin; amlodipin

Corresponding author*: Serkan Demirkan, Kirikkale University, Department of Dermatology, Kirikkale / TURKEY

E-mail: serkan.demirkan@yahoo.com.tr

Recevied: 22.12.2017 accepted: 28.05.2018

Doi: $10.18663 /$ tjcl. 370070 


\section{Introdcution}

Light-skin relationship is very complex and wide-ranging in physiopathological sense and is a concept intersected by deep structural features, general immunology, skin immunology, light physics, light biology and carcinogenesis[1]. Among the undesirableeffects of thelight is thelightsensitivity. Photosensitivity is an abnormal response that occurs within minutes, hours, or days against the sunlight and lasts for weeks, months, or even longer. (2). It is tried to be explained by the light wavelength in the solar spectrum (ultraviolet (UVA), Ulltraviyole B (UVB))[3].

The lowest radiance leading to a perceptible erythema with UVA or UVB is called minimal erythema dose(MED) and is measured in J/ cm2[4]. The most common and reliable method of identifying a causative phototoxicity is to monitor the change of MED, especially with UVA, after using the drug[4].

The photosensitivity induced by drugs or chemicals has become increasingly common due to the use of a greater number and variety of therapeutic agents[5]. It is aimed to determine whether dihydropyridine-derived calcium channel blockers cause photosensitivity from hypertension drugs which called phototoxic.

\section{Material and Methods}

Due to the Phase 4 drug study, from the Clinical Research Ethics Committee of Adnan Menderes University (Protocol: 2012/05) and from the Department of Turkey Pharmaceutical Affairs (Number: 144 297, E-no: 1011149) has been allowed. Informed consent was obtained from the patients included in the study. For the significance of the study, a minimum of 30 patients had to be included in the study in order for the alpha value to be 0.95 and the beta value to be 0.80 . Patients who were decided to use dihydropyridine-derived calcium channel blocker (nifedipine, amlodipine) as monotherapy by cardiology and nephrology physicians due to hypertension were included in the study. The volunteers to participate in the study were provided from the outpatient clinics of cardiology and nephrology. People who use drugs other than dihydropyridine-derived calcium channel blockers for any other reason, those with claustrophobia, those with known photosensitivity, those with light-triggered dermatosis, those with cataracts, those with skin malignancy were excluded.

The cardiologist or nephrology specialist has identified the drug and dose to be given due to the hypertension. Nifedipine $30 \mathrm{mg}$ tb, amlodipine $5 \mathrm{mg}$ tb, and amlodipine $10 \mathrm{mg}$ tb were used as oral monotherapy
In the study, phototherapy cabinet named Waldmann UV 7002 was used. The head, trunk and upper extremities of the patients were covered with a special garment. Eight open areas of $1 \mathrm{~cm} 2$ were left on the backs of the patients. Eight different doses of UVA were applied to these 8 areas, increasing from $2 \mathrm{j} / \mathrm{cm} 2$ to $16 \mathrm{j} / \mathrm{cm} 2$; After 24 hours, the first area was checked which had significant erythema.(Figure 1) This value was determined as minimal erythema dose (MED1). MED values for UVA were measured before treatment and on day 7 of treatment to determine the early phototoxic response (MED2) .

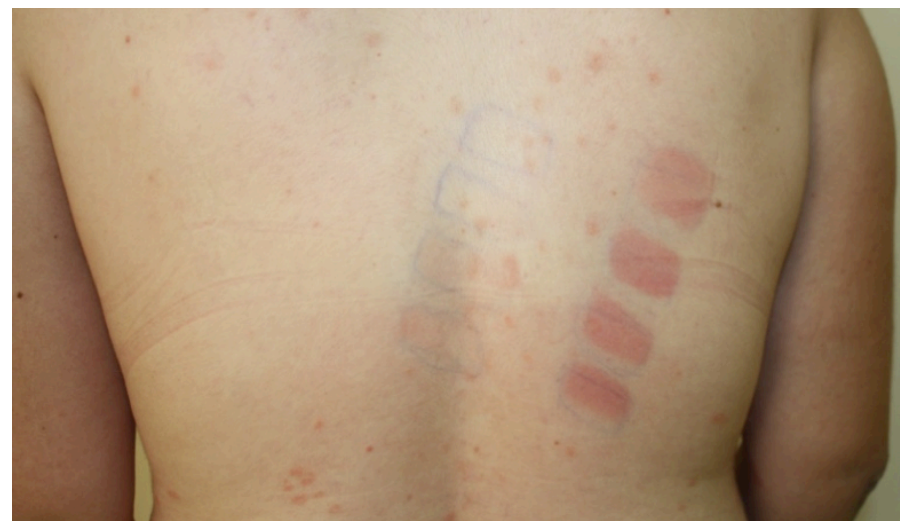

Figure 1: A patient with a MED value of $2 \mathrm{j} / \mathrm{cm} 2$ (increasing $2 \mathrm{j} / \mathrm{cm} 2$ from the top left) after 24 hours of UVA administration.

Statistical analysis was performed using SPSS 21.0 software package. In comparisons between MED1 and MED2, the student's t-test was applied to numerical data that followed a normal distribution, while the Mann-Whitney $U$ test was applied to data that did not follow a normal distribution. The Pearson correlation test was applied to normally distributed measurements, and the Spearman correlation test was applied to data that did not follow a normal distribution. The statistical significance value was accepted as $p<0.05$.

\section{Results}

Thirty-nine hypertensive patients, 20 female and 19 male, were included in the study. The ages of the patients ranged from 49 to 65 and the median was 57.According to the Fitzpatrick classification, 27 of the patients were skin type 3, 12 of them were skin type 2. 27 patients received amlodipine, and 12 patients received nifedipine treatment. A difference between MED1 and MED2 values was found in 7 of 39 patients.(Table 1) There was a decrease in MED (MED2) value in 5 patients, an increase in MED (MED2) value in 2 patients, and no difference between MED 1-2 values in 32 patients. The mean value of MED 1 values was 10.62, while the mean value of MED 2 values was 10.36. There was no significant difference between MED 1-2 values $(p=0,206)$. Three out of 20 females and 4 out of 19 males had MED changes. There was no gender effect in the MED change $(p=0.695)$. The median 
age of those with MED changes was 57, and the median age of those without MED changes was 58. Age did not seem to have any effect on MED change $(p=0,164)$. There were differences between MED 1-2 in 2 of 27 patients with skin type 3 and between MED1-MED2 in 5 of 12 patients with skin type 2. The skin type had no effect on MED changes $(p=1,00)$.

There was no effect on MED change of active drug $(p=0,105)$ and drug dose $(p=0,222)$ when same active ingredient was used.

\begin{tabular}{|c|c|c|}
\hline & MED1 & MED2 \\
\hline $6 \mathrm{j} / \mathrm{cm} 2(\mathrm{n})$ & 1 & 2 \\
\hline $8 \mathrm{j} / \mathrm{cm} 2(\mathrm{n})$ & 6 & 8 \\
\hline $10 \mathrm{j} / \mathrm{cm} 2(\mathrm{n})$ & 19 & 16 \\
\hline $12 \mathrm{j} / \mathrm{cm} 2(\mathrm{n})$ & 8 & 9 \\
\hline 14 j/cm2(n) & 3 & 2 \\
\hline $16 \mathrm{j} / \mathrm{cm} 2(\mathrm{n})$ & 2 & 2 \\
\hline
\end{tabular}

\section{Discussion}

Light sensitivity may vary depending on the person's skin phototypic (DFT), immunological status, genetic predisposition, solar exposure, topical or systemic drugs or nutrients used.

Increased light sensitivity with drug / chemistry describes the interaction of ultraviolet radiation in the skin with a drug / chemical [1,2]. Light sensitivity due to exogenous agents such as drugs manifests itself as cytotoxicity and photoallergic reaction. The most common of these is phototoxicity[1,2]. Phototoxic reactions do not engage in immunological mechanisms; are photochemical reactions due to dose [1,2]. Phototoxicity occurs in everyone when appropriate irradiation and exposure of the drug is sufficient [1,2]. Different agents are blamed for linked photosensitization. Some of these drugs have been evaluated clinically in a large number of patients or healthy volunteer studies and their photosensitivity properties have been proven. Some medicines are accused on the basis of cases. In terms of photosensitivity, fluoroquinolone group antibiotics, NSAIDs (non-steroidal anti-inflammatory) drugs, hypersecin and tenidap have been studied for a few cases [6-11].

It is argued that dihydropyridine derivative and other group of calcium channel blockers may cause photosensitivity in basic dermatology sources[12].The issue of whether photosensitivity occurs in all of the patients using dihydropyridine-derived calcium channel blocker or rarely in the idiosyncratic anomaly has not been addressed.
In the study conducted by the Photobiology Unit of Dermatology Department of Dundee University, 401 people were evaluated; the average of the MED values of those who used a single drug or multiple drugs was compared to the MED values of those who did not use any drugs [13]. Photosensitization was detected in people using calcium channel blockers, NSAIDs and phenothiazines. However, the active ingredients of the drug groups used by the patients are not mentioned in this study. Phototype of the skin as well as our study did not cause statistically significant difference in photosensitivity. In this study UVB was used but UVA was used in our study. The phototoxic reaction occurs more frequently with UVA. Therefore our study seems more rational $[13,14]$. The mean MED values were compared in this study.In our study, we compared the pre-and post-drug MED averages as well as individual measurements for each patient.

Ferguson and Leeming's; In study investigating the phototoxicity of tenidap, 6 different wave lengths of light including UVA and visible light were used[9]. Only UVA was used in our study. This may be one of the missing aspects of our study, although the expected light spectrum of phytotoxicity is UVA, but some drugs are thought to cause photosensitivity with UVB and visible light $[8,13]$. Another difference in our study from this study is that patients' weights were not measured. When phototoxicity is thought to be related to the plasma level of the drug and the dose, it may be useful to measure the patients' weights and compare them to the drug dose. Non-measurement of the weight of patients can be counted as a limitation of our study.

In a study conducted by Ferguson and Dawe comparing the photosensitivity of grepafloxacin with ciprofloxacin, sudden phototoxicity and late phototoxic response were evaluated; it has not been evaluated in our work [9]. Failure to follow the sudden erythema response; lack of long-term follow-up of UVA-applied skin areas of patients in terms of milia formation and pigmentation increase can be counted as the limitation of our study. In addition, while the placebo group in this study, our study had no placebo group. However, our study provided a comparison with the normal population, which had MED values measured before drug use. In this case, the placebo group may not be necessary.

In phototherapy treatments, all medicines and herbal products used in determining the MED for the patients and in the course of the dose increase during the treatment should 
be questioned. In addition, physicians may be informed about the seasonal variation or preference of drugs that cause photosensitivity [15].

\section{Conclusion}

Detection of photosensitizing agents may not be easy. Diagnosis tests such as the detection of MED value are important when considering the use of multiple drugs and the difficulty of obtaining the drug story. The half-life of the drug and whether the patient uses other photosensitizer drugs affects the reliability of the tests. In our study, it was concluded that the photosensitizing properties of dihydropyridinederived calcium channel blockers were absent. A 7 day period is sufficient for an early phototoxic response, but a 7 day period may not be enough for a late phototoxic response. This is the lack of study. Although 39 patients seem to be statistically significant enough, dihydropyridine-derived calcium channel blockers may be insufficient to reflect the characteristics of the whole population when considering the number of hypertensive patients using it. Studies with more patients can be done in this regard. It is open to investigate what may happen when these drugs are used concurrently with other medicines, what will be the effect in different age groups and over time.

\section{Declaration of conflict of interest}

The authors received no financial support for the research and/or authorship of this article. There is no conflict of interest.

\section{References}

1. Moseley H. Elementary photobiology and photophysics. J. Ferguson, J.S.Dover(Eds). Photodermatology (pp.:9-13). London: Manson Publishing, 2006.

2. Kochever IE, Taylor CR, Krutman J. Fundamentals of cutaneous photobiology and photoimmunulogy. In:K.Wolff, L.A.Goldsmith, S.I.Katz, B.A.Gilchrest, A.S.Paller, D.J.Leffel (eds). Fitzpatrick's Dermatology in General Medicine (pp.:797-809). 7th ed. New York: McGraw-Hill Book Company, 2008.

3. Scheinfeld NS, Chernoff K, DerekHo MK, LiuYC.Drug-induced photoallergic and phototoxic reactions - an update. Expert Opin Drug Saf 2014:321-340.

4. Endres L, Breit R. UV radiation, irradiation, dosimetry. In: Krutmann J, Höningsmann H, Elmets CA, Bergstresser PR (eds). Dermatological phototherapy and photodiagnostic methods (pp.:3-53). Berlin: Springer Verlag, 2000.
5. Moseley H. Phototest equipment. In: J Ferguson, J.S.Dover (Eds). Photodermatology (pp.:14-20). London: Manson Publishing 2010.

6. Becker L, Eberlein-Konig B, Przybilla B. Phototoxicity of Nonsteroidal Antiinflammatory Drugs: In Vitro Studies with Visible Light. Acta Derm Venereol 1996; 76: 337-40.

7. Dawe RS, Ibbotson SH. Drug-induced photosensitivity. Dermatol Clin 2014: 363-68.

8. Ferguson J, Leeming MRG. Lack of photosensitising potential of tenidap, a novel anti-rheumatic agent. Br J Clin Pharmac 1995; 39: 63-66.

9. Ferguson J, Dawe R. Phototoxicity in quinolones: comparison of ciprofloxacin and grepafloxacin. J Antimicrob Chemother 1997 ;40: 93-98.

10. Jeon HY, Kim JK, KimWG, Lee SJ. Effects of oral epigallocatechingallate supplementation on the minimal erythemadoseand UV-induced skin damage. Skin Pharmacol Physiol 2009; 22: 137-41.

11. Beattie PE, Dawe RS, Traynor NJ, Woods JA, Ferguson J, Ibbotson $\mathrm{SH}$. Can St John'swort (hypericin) ingestion enhance the erythemal response during high-dose ultraviolet $\mathrm{A} 1$ therapy? $\mathrm{Br}$ J Dermatol 2005: 1187-91.

12. Taylor DK, Anstey AV, Coleman AJ, et al: Guidelines for dosimetry and calibration in ultraviolet radiation therapy: a report of a British Photodermatology Group workshop. Br J Dermatol 2002; 146: 755-63.

13. Jameron H. Dawe R.S. Photosensitizing drugs may lower the narrow-band ultraviolet $\mathrm{B}(\mathrm{TL}-01)$ minimal erythema dose. $\mathrm{Br} \mathrm{J}$ Dermatol 2000; 142: 370-93.

14. Neuman NJ, Lehmen P. Photodiagnostic Modalities. In: J.Krutmann, H.Hönigsman, C.A.Elmets, PR. Bergstresser (Eds), Dermatological Phototheraphy and Photodiagnostic Methods. (pp.:367-376.) Berlin: Springer 2009:

15. Kayaalp O. Kardiyovasküler sistem; kalsiyum kanal blokerleri. In: O. Kayaalp(Ed), Türkiye ilaç klavuzu 5 (pp.:99-104). İstanbul: GoldenPrint 2007. 